\title{
Civil Rights Law at Work: Sex Discrimination and the Rise of Maternity Leave Policies
}

\section{Citation}

Kelly, Erin and Frank Dobbin. 1999. Civil rights law at work: Sex discrimination and the rise of maternity leave policies. American Journal of Sociology 105(2): 455-492.

\section{Published Version}

http://dx.doi.org/10.1086/210317

\section{Permanent link}

http://nrs.harvard.edu/urn-3:HUL.InstRepos:3202909

\section{Terms of Use}

This article was downloaded from Harvard University's DASH repository, and is made available under the terms and conditions applicable to Other Posted Material, as set forth at http:// nrs.harvard.edu/urn-3:HUL.InstRepos:dash.current.terms-of-use\#LAA

\section{Share Your Story}

The Harvard community has made this article openly available.

Please share how this access benefits you. Submit a story.

\section{Accessibility}




\title{
Civil Rights Law at Work: Sex \\ Discrimination and the Rise of Maternity Leave Policies ${ }^{1}$
}

\author{
Erin Kelly and Frank Dobbin \\ Princeton University
}

\begin{abstract}
By the time Congress passed the Family and Medical Leave Act of 1993, many employers had created maternity leave programs. Analysts argue that they did so in response to the feminization of the workforce. This study charts the spread of maternity leave policies between 1955 and 1985 in a sample of 279 organizations. Sex discrimination law played a key role in the rise of maternity leave policies. Building on neoinstitutional theory, this article explores how the separation of powers shapes employer response to law. Details of the law are often specified in administrative rulings - the weakest link in the law because they can be overturned by the courts and by Congress. Yet an administrative ruling requiring employers with disability leave programs to permit maternity leave, which employers successfully fought in the courts, was at least as effective as the identical congressional statute that replaced it. In the American context, the legal vulnerability of administrative rulings can draw attention to them, thus making the weakest link in the law surprisingly powerful.
\end{abstract}

\section{INTRODUCTION}

In the first debate of the 1996 presidential campaign, Bob Dole (Washington Post 1996, p. A12) argued that Congress should not have used the "long arm of the federal government" in 1993 to force employers to offer

\footnotetext{
${ }^{1}$ We are grateful for support from the National Science Foundation (SES-8511250), the Alfred P. Sloan Foundation, and Princeton's University Committee on Research. Thanks to John Meyer, John Sutton, and W. Richard Scott for their collaboration in the survey and to Paul Allison, Paul DiMaggio, Jennifer Glass, Richard Lempert, John Meyer, Paul Osterman, German Rodriguez, Louise Roth, Mark Schoenhals, John Skrentny, Hiromi Taniguchi, Jane Waldfogel, Bruce Western, participants in Princeton's Workshop on Economic Sociology, and AJS reviewers for suggestions. An earlier version of this article was presented at the 1997 American Sociological Association meeting in Toronto. Direct correspondence to Erin Kelly, Department of Sociology, 2-N-1 Green Hall, Princeton University, Princeton, New Jersey 08544-1010. E-mail: elkelly@princeton.edu
}

(C) 1999 by The University of Chicago. All rights reserved. 0002-9602/2000/10502-0004\$02.50 
parental leaves. Most employers were already providing maternity leave in response to the growing ranks of women workers, Dole argued. Business leaders had made the same point in fighting the Family and Medical Leave Act (FMLA) of 1993. James A. Klein, the manager of employee benefits for the United States Chamber of Commerce, argued: "There is a growing sense, as the demographics of our work force change, that parental leave is a good benefit to have. . . . A recent Bureau of National Affairs survey showed that $90 \%$ of companies grant maternity leave... . We think that's terrific, so long as it's voluntary" (quoted in Pear 1985, p. 16). In a letter to the Washington Post, the Small Business Association stated: "In the absence of any government mandate . . between 74 and 90 percent of all businesses are already addressing the problem" (Jasinoski 1991, p. 3C).

It is true that employer treatment of maternity had changed before passage of the FMLA in 1993. In the late 1950s, only 5\% of those in our sample of medium and large employers offered maternity leave; by 1985, over half offered it. In the late 1960s, many corporations still required pregnant women to resign; by the late 1970s, few did so (Fryburger 1975). Many women took advantage of these changes in employer policy. In the early 1960s, only one-sixth of employed women who bore children took leaves; by the mid-1980s fully half were taking leaves (O'Connell 1990).

Employers created maternity leave programs in the 1970s and 1980s, but not as a "voluntary" response in "the absence of any government mandate," as politicians, business leaders, and scholars have argued. Employers responded to three kinds of government mandates. First, in 1972, the Equal Employment Opportunity Commission (EEOC) ruled that employers who allowed leaves for disabling medical conditions must allow them for maternity. Failure to do so constituted sex discrimination under the Civil Rights Act of 1964. As early as 1973, a survey (Bender 1973, p. 61) found that $58 \%$ of large employers had responded with new maternity leave policies. Second, in 1978, after the Supreme Court overturned the EEOC ruling, Congress passed a statute codifying the 1972 EEOC requirements. Third, some states went a step further. California required employers to allow job-guaranteed maternity leaves, regardless of their temporary disability policies.

We show that these legal changes had a profound, if little-recognized, influence on workplace maternity leave (Meyer and Rowan 1977; Dobbin and Sutton 1998). Most students of maternity leave programs neglect these policies, in some cases because they use cross-sectional data that make it hard to observe the effects of legal changes (Glass and Fujimoto 1995; Goodstein 1994; Ingram and Simons 1995; Milliken, Martins, and Morgan 1998). But even those who focus on the legal environment tend to overlook early maternity leave law. Ruhm and Teague (1997, p. 133) argue, "Prior 
to 1993 there was no federal law requiring U.S. employers to offer parental leave," despite the fact that 1972 and 1978 laws required many employers to offer maternity disability leaves and pay (see also Klerman and Liebowitz 1997). Like Bob Dole and the Chamber of Commerce, most scholars discount the role of public policy and privilege the role of the labor market when explaining employers' leave policies.

We build on neoinstitutional studies that explore why Americans see business practices that are driven by public policy as driven by market forces (Fligstein 1990, 1996; Dobbin and Sutton 1998). Americans tend to underestimate the importance of policy in part because the federal government appears to be weak. We argue that one basis of the federal government's perceived weakness, the separation of powers, can produce a peculiar sort of policy efficacy. In separating governing powers, the Constitution is thought to weaken the state by making administrative and case law and, to a lesser extent, legislation susceptible to legal challenges. History has created a natural laboratory that allows us to examine the relative efficacy of an administrative ruling and a parallel, subsequent, congressional statute. Our findings challenge the conventional wisdom that administrative regulations are ineffective when their legal standing is uncertain. Because the 1972 EEOC ruling was contested in court, and ultimately because the administrative branch's authority to make law is tenuous, the ruling won press attention that popularized maternity leave policies. Yet perhaps because the ruling was struck down by the Supreme Court, politicians and scholars have failed to recognize its effects.

We also provide what we believe to be the first test of the relative efficacy of equal opportunity and affirmative action laws in changing employer practices, and here our findings confirm the conventional wisdom that affirmative action laws are more effective. We test these hypotheses about the effects of public policy in the context of competing hypotheses about female labor force participation and about employer sensitivity to the risk of legal sanction. Like Bob Dole and the Chamber of Commerce, most labor economists assume that employers adopted maternity leave in response to the growing feminization of the workforce. We look at the effects of industry feminization and trends in feminization. Students of law and regulation, on the other hand, argue that employers comply with the law when the risk of legal sanction is high. We compare the effects of a contested administrative ruling of uncertain legal standing with those of an uncontested congressional statute. We also operationalize the risk of legal sanction with a measure of federal lawsuits dealing with maternity leave. The feminization and legal sanction hypotheses fare poorly in our analyses.

Our analysis relies on data from a stratified random sample of California, New Jersey, and Virginia employers. After charting the history of maternity leave law and deriving hypotheses about the effects of changes 
in the law, we review theories that suggest rival hypotheses. We then model the adoption of maternity leave policies in a sample of 279 organizations, 148 of which established formal leave policies between 1955 and 1985. We look at the adoption of written maternity leave policies, which guarantee that a worker can return to her job, or to a similar job, after being away from work due to pregnancy, childbirth, or infant care. ${ }^{2}$

\section{TRANSLATING LAW INTO ORGANIZATIONAL RULES}

Classical organizational theorists paid scant attention to the role of the state in shaping the behavior of organizations. Neoinstitutional theorists have remedied this, showing that a variety of contemporary organizational features had their origins in public policy. Fligstein (1990) shows that antitrust amendments encouraged firms to adopt the conglomerate form. Roy (1997) shows that the modern private corporation inherited the structure of the 19th-century, public-purpose corporation. Baron, Dobbin, and Jennings (1986) show that World War II labor market regulations encouraged firms to develop personnel systems. Before these neoinstitutional studies, the role of the state had faded in scholarly accounts of corporate attributes, arguably because antistatist sentiments led Americans to articulate market rationales for all corporate practices.

Neoinstitutionalists have sought to understand the central paradox of U.S. business regulation - how a seemingly weak state can shape corporate practice. While some theorists had described the relationship between the state and organizations as "coercive" (DiMaggio and Powell 1983), empirical studies found that the U.S. state often influences corporate behavior without using a clear, coercive mandate. Neoinstitutionalists first explored why firms respond to ambiguous legislation. They found that ambiguous federal laws could produce elaborate compliance activities among organizations uncertain of what is required of them. Ambiguity in legislation leads firms to invent compliance measures on their own, to be tested by the courts (Edelman 1992; Dobbin et al. 1993). The measures they invent feed into the next round of statute making (Carruthers and Halliday 1998, p. 45). Professional groups-lawyers and personnel managers-turned legal ambiguity into a professional asset, by exaggerating the risk of litigation to win corporate resources (Edelman et al. 1992) and by lobbying executives to create extensive, legalistic personnel systems (Sutton and Dobbin 1996).

\footnotetext{
${ }^{2}$ Over the past 40 years, maternity leave has been linked to disability leave, sick leave, parental leave, and family leave. We consider policies covering maternity to be maternity leave policies, regardless of the label used.
} 
The Paradox of Administrative Law

Our primary theoretical goal is to explore the effects of another apparent weakness of the U.S. state, the separation of powers. The separation of powers permits all three branches of government to make law, but it also opens the laws made by each branch to challenge. Congress writes laws, often using abstract language that demands interpretation. Federal agencies then interpret the law, issuing regulations that begin to define compliance. The courts can rule against these regulations on the grounds that they are inconsistent with legislation or with constitutional law. Affected parties often challenge administrative and judicial rulings, and free riders often await final disposition of the challenges brought by their peers. Congress also has the power to write laws that directly address case law and administrative law, validating some interpretations of previous statutes and overruling others. In short, case law trumps administrative law, and legislation trumps everything but the Constitution.

Most see the separation of powers as weakening the state, because it renders federal edicts vulnerable to legal challenge and reversal. It makes administrative law particularly vulnerable. Scholars of law and regulation from both left and right (Sunstein 1996; Posner 1997) suggest that corporate responsiveness to the law is a function of the risk of sanction. The likelihood of sanction in the federal courts is greater in the case of congressional acts than in the case of administrative law, because legislation is less susceptible to legal challenge and reversal. It follows that, all else being equal, legislation should be more effective than administrative law at changing employer practices.

The history of early maternity leave law sheds light on the process by which law - both statutes and administrative rulings - are translated into organizational practices. With the Civil Rights Act of 1964, Congress outlawed sex discrimination in employment. The EEOC, established to administer the law, at first defined sex discrimination narrowly. In 1972, it expanded the definition to include pregnancy discrimination. That definition was successfully challenged in court by General Electric and was then revived by Congress in the Pregnancy Discrimination Act of 1978. We use this historical sequence to assess the relative efficacy of administrative law. We compare the contested administrative ruling with the virtually identical congressional act that replaced it. Both the 1972 ruling and the 1978 act required employers to treat pregnancy-related disability on par with other short-term disabilities - to offer leaves and pay for pregnancy if they offered them for other medical conditions. Despite the fact that it was overturned by the Supreme Court, the 1972 EEOC ruling was surprisingly effective at changing employer policies.

We argue that in the United States, where employment law is enforced 
reactively through litigation rather than proactively through administrative scrutiny, employers respond to the visibility of new laws and the perceived risk of litigation rather than to the objective risk of legal sanction. Press attention to legal battles increases the perceived risk of sanction, in part because it increases the visibility of the law and in part because negative publicity is a potent sanction itself. In other words, employment law may work through such informal sanctions as bad press as well as through such formal sanctions as costly litigation (Suchman and Edelman 1996; McCann 1998). Thus litigation and press coverage can serve to promulgate a new federal edict, even when the goal of the litigation is to overturn the edict. Paradoxically, then, administrative rulings may elicit organizational response because they are inherently susceptible to court challenges.

\section{Affirmative Action versus Equal Opportunity Laws}

Our second goal is to examine the relative effectiveness of equal opportunity and affirmative action laws. Equal opportunity laws require employers to treat all employees equally, regardless of characteristics such as sex, race, and religion. Affirmative action law, as Kennedy and Johnson defined it, encourages positive efforts to improve opportunities for disadvantaged groups (see Skrentny 1996). Activists within the Civil Rights and women's movements have long debated the merits of affirmative action in employment. While many contend that it improves opportunities for disadvantaged groups, others contend that it smacks of "special treatment" and thus lacks the legitimacy conferred by the 14th amendment's language of equal protection.

Few previous studies have explored the efficacy of affirmative action laws in the realm of employment. Early labor market studies showed that employers covered by affirmative action law were more likely to add black men to their payrolls than were employers covered only by equal opportunity law (Ashenfelter and Heckman 1976; Leonard 1984). Like the authors of these early labor market studies, we compare two groups of employers: one exposed to an equal treatment provision and the other exposed to both that provision and an affirmative action law. The federal Pregnancy Discrimination Act of 1978 required equal treatment of pregnancy and other disabling medical conditions. California's 1978 "affirmative action" maternity law additionally required employers to offer job-guaranteed maternity leave. We find that the affirmative action law had a significant net effect.

Next, we chronicle the evolving treatment of pregnancy under sex discrimination law, developing hypotheses about the effects of three different 
policy approaches. We then review competing theories of employer maternity leave provision before turning to our central analysis.

\section{THE LAW AND MATERNITY LEAVE}

We examine the effects of three laws to make two critical comparisons. First, we examine two substantively similar laws: a contested administrative ruling and an uncontested congressional act. We compare employer response to the EEOC guidelines of 1972 and the Pregnancy Discrimination Act of 1978. Second, we examine two substantively different laws: an equal treatment law requiring employers to match maternity benefits to disability benefits and an affirmative action law requiring all employers to offer maternity leave. We compare employers subject to the Pregnancy Discrimination Act of 1978 with those additionally subject to California's 1978 amendments to its Fair Housing and Employment law.

\section{Before Maternity Leave Laws}

Before the early 1970s, the American state did little to promote maternity leave (Kamerman, Kahn, and Kingston 1983). During World War II, the Department of Labor's Women's Bureau recommended that employers guarantee the jobs of women who were absent due to pregnancy and maternity. But most employers continued to require pregnant women to resign from their jobs (Frank and Lipner 1988, p. 15; Silverman 1943). The Equal Pay Act of 1963 required employers to pay men and women the same wages for the same work, and the Civil Rights Act of 1964 outlawed employment discrimination based on sex. However, neither act mentioned maternity or pregnancy. In 1966, the Equal Employment Opportunity Commission (EEOC), created to administer the employment provisions (Title VII) of the Civil Rights Act, stated that providing "truly equal employment opportunities" meant guaranteeing the jobs of women who were absent from work due to maternity and childbirth (EEOC 1966, p. 40). Yet the EEOC also told employers that it was not illegal to exclude maternity from disability leave programs (Vogel 1993, pp. 64-65).

Employers felt little pressure to offer maternity leave in the years after the passage of the Civil Rights Act. A 1967 study of large employers, conducted by the Bureau of National Affairs (BNA), found that $18 \%$ still required pregnant employees to resign (BNA 1967, p. 20). The vice president of the First National Bank of Cincinnati pointed to the EEOC's ambivalence in explaining his company's resignation policy: "It is my understanding that while the EEOC favors the concept of maternity leaves, it has not agreed to a policy statement. Until such time, I shall follow my 
former policy" (quoted in BNA 1967, p. 20). During the 1960s, civil rights legislation did little to encourage employers to offer maternity leave.

\section{The 1972 EEOC Ruling: Promulgation by Litigation}

In March of 1972, the EEOC issued new Guidelines on Discrimination because of Sex that defined pregnancy discrimination as an element of sex discrimination. Employers could not refuse to hire, train, or promote a woman because of pregnancy (29 Code of Federal Regulations 1604 [1972]). Neither could they fire a woman because of pregnancy. The guidelines also directed employers to treat pregnancy-related disabilities as they treated other disabilities that keep workers away from their jobs for short periods. Employers who provided leaves, health insurance, or income replacement for nonoccupational injury and illness were required to do the same for pregnancy-related disabilities. The EEOC guidelines also suggested that employers who failed to allow leaves for pregnancy-related disability were guilty of discrimination, unless they could prove a business necessity for forbidding leaves.

Using the EEOC guidelines, the EEOC and unions sued employers over their maternity leave benefits. Employers fought back by charging that the EEOC guidelines were an illegal deviation from Congress's intent in the Civil Rights Act of 1964. The EEOC's targeted lawsuits produced a great deal of publicity for the new maternity leave regulations. The guidelines were effective, paradoxically, because as administrative law they were vulnerable to reversal by the courts; when employers fought the new regulations, they helped generate even more publicity for the issue of maternity leave. The EEOC apparently recognized this when they initiated suits against high-profile employers, seeking both a favorable Supreme Court ruling and publicity for the guidelines. While the Supreme Court overturned the guidelines in 1976, many employers who followed the legal contest did not wait for the standing of the guidelines to be clarified.

The women's movement and the EEOC regulations. - We show below that after the EEOC ruling, employers were more likely to create maternity leave programs. Some might argue that the law was merely a mediating force and that the women's movement pressured the EEOC and employers to change their maternity leave policies. Did the women's movement prompt the EEOC ruling and employers' adoption of maternity leave? We now take a brief detour to answer this question. First, we note that scholars of the women's movement give feminists within the federal government a central role in stimulating the women's movement (see Harrison 1988; Costain 1992). Kennedy's Commission on the Status of Women gave rise to state-level commissions, and it was at a 1966 con- 
ference of these commissions that feminists encouraged Betty Friedan to found the National Organization for Women (NOW) as an external lobbying body (Harrison 1988, chap. 9; Costain 1992, pp. 44-45; Skrentny, in press). Second, by the early 1970s, NOW and other women's movements groups were functioning autonomously, but they were not concentrating on federal maternity leave policy. At this time, NOW was busy lobbying states for passage of the Equal Rights Amendment and lobbying the EEOC to end discrimination in job advertising.

Instead, it was the federal Citizens' Advisory Council on the Status of Women (successor to Kennedy's Commission) that led the charge to change federal policy on maternity leave. The Council developed sample maternity leave policies for federal employees, pressed the EEOC for a ruling on maternity leave, and provided the language for the 1972 maternity leave guidelines (Citizens' Advisory Council on the Status of Women 1971, 1973; Vogel 1993, pp. 62-65). The historical evidence suggests that feminists within the federal government lobbied for the maternity leave ruling, which later led employers to change their practices.

The EEOC guidelines and employer response.-Contemporaneous studies showed that large employers responded quickly to the new EEOC regulations. A Prentice Hall study of 108 large employers found that more than half were at least considering new maternity leave policies in the wake of the EEOC's guidelines (Hyatt 1972, p. 20). EEOC Commissioner Ethel Bent Walsh reported in 1974 in the Labor Law Journal that over three-fourths of banks and insurance companies had liberalized their maternity leave policies and benefits "as a direct result of [EEOC] Guidelines" (Walsh 1974, pp. 153-54). One study found that between 1972 and 1975, two-fifths of employers made major changes in their maternity leave policies (BNA 1975). Another found that the number of firms offering maternity leave nearly tripled between 1969 and 1978 (Kamerman et al. 1983, p. 56). We hypothesize that employers responded to the EEOC's new position with new maternity leave policies.

HyPOTHESIS 1.-In the wake of the EEOC guidelines, employers were significantly more likely to create maternity leave policies.

Legal challenges to the EEOC ruling. - After the EEOC issued the 1972 guidelines, the Commission began a legal campaign against large, highprofile employers. Some of these employers, notably General Electric, challenged the EEOC's interpretation of Title VII. The G.E. case (General Electric Co. v. Gilbert et al., 97 Sup. Ct. 401 [1976]) dealt directly with disability insurance (i.e., income replacement) during leaves but drew attention to the wider issue of maternity leave. Using the EEOC guidelines, the United Electrical Workers union initiated a class action suit, in which they claimed that G.E.'s disability benefits program discriminated against 
pregnant women. General Electric argued that the EEOC's interpretation of Title VII as covering pregnancy ran counter to the legislative history of the Civil Rights Act.

Before the Supreme Court's 1976 ruling in favor of G.E., both the District Court of Virginia and the United States Court of Appeals for the Fourth Circuit ruled that G.E. had discriminated against pregnant employees (Fryburger 1975). These decisions created modest financial sanctions and tremendous negative publicity for the company. In April of 1974, district court judge Robert Merhige ruled that G.E. must treat pregnancy as it treats other temporary disabilities: "To isolate such a disability for less favorable treatment in a scheme purportedly designed to relieve the economic burden of physical incapacity is discrimination by sex" (quoted in National Underwriter 1974, p. 4). G.E. had argued that because pregnancy is voluntary, it is not like other disabilities. The court found that because G.E. does not exclude any other disabilities, they cannot exclude pregnancy-related disabilities: "That this is sex discrimination is self-evident" (quoted in National Underwriter 1974, p. 4). The court of appeals upheld this decision in 1976.

Late in 1976, the Supreme Court reversed the lower court decisions in the G.E. case, ruling that employers who treat pregnancy differently from other nonoccupational disabilities are not guilty of sex discrimination. Justice Rehnquist, for the Court, argued that excluding a condition from disability leave and benefit coverage as "a subterfuge to accomplish a forbidden discrimination," in this case against women, would be illegal if the condition were similar to covered conditions. But pregnancy is "not a 'disease' at all, and is often a voluntarily undertaken and desired condition" (General Electric Co. v. Gilbert et al., 9). The Court rejected Judge Merhige's position that maternity should be treated like cosmetic surgery, which is voluntarily undertaken, and like sports injuries, which occur during recreational activities that carry known risks. The G.E. challenge seemed to have succeeded in the courts, but the notoriety it brought encouraged employers to add maternity leave policies.

Press coverage as the mediating force.-The EEOC's announcement of the guidelines produced a brief burst of press attention, but legal challenges generated the ongoing publicity that brought the EEOC's position to the attention of most employers. The 1972 guidelines made the first page of the New York Times (March 31, 1972), the sixth page of the Wall Street Journal (April 3, 1972), and the tenth page of section three of the Los Angeles Times (April 1, 1972). The New York Times reported that, "In its most sweeping revision of its guidelines on discrimination because of sex since they were first adopted in 1966, the employment commission now says that to deny a woman a job because she is pregnant is, on its face, a violation of the Civil Rights Act of 1964. . . In addition, disabilities 
related to pregnancy, including recovery from childbirth, miscarriage, and abortion, should be treated by employers the same as any other temporary disability in terms of leave" (New York Times 1972, p. A1).

In April of 1974, the New York Times reported that in the two years since the EEOC's guidelines were issued, the commission had sued 11 large employers for maternity discrimination, with 111,052-employee du Pont at the top of the list. In reporting on these suits, the Times warned, "Just as women have always know that it is impossible to be 'a little bit pregnant,' so the nation's employers are learning-from the Federal Government - that it is imprudent to be a little bit prejudiced against a pregnant employee" (Dullea 1974, p. 41). Specialist journals also advised employers to add maternity leave. Harry Edwards argued in the Labor Law Journal in 1973 (p. 421), "reinstatements after childbirth will probably be required unless the employer can show that there is some compelling 'business necessity' which justifies a refusal to reinstate." Business Week reported that after the district court's decision in the G.E. case in April of 1974, the EEOC filed 130 pregnancy discrimination suits and issued warnings to another 250 companies. The union that fought the case against G.E. soon brought charges against another 73 employers, and Business Week (1976, p. 41) noted that "Companies on the firing line include Westinghouse, RCA, Chrysler, Sperry Rand, Pennwalt, Honeywell, Philco-Ford, and Phelps Dodge." Given the prominence of the EEOC guidelines and pursuant lawsuits at the time, it is striking that a quartercentury hence, politicians, managers, and scholars have forgotten the role of the state in popularizing maternity leave.

The G.E. case and related litigation received much more press coverage than the original guidelines had. While the adoption of the guidelines merited one or two articles in each major daily paper we examined, the G.E. case was the subject of 20 New York Times articles between 1972 and 1976 and was covered widely in the pages of Business Week, Fortune, and Forbes. The district court and court of appeals decisions of 1974 and 1976, backing the guidelines, received particularly extensive coverage. Figure 1, which charts New York Times articles on maternity leave issues from 1970 to 1984, illustrates this. There was a dramatic rise in the number of articles in 1972, the year that saw the issuance of the EEOC guidelines and the initiation of the G.E. case. The number of articles remained high for the course of the litigation.

We hypothesize that early lawsuits generated publicity about the new regulations and so led employers to install maternity leave programs, despite the fact that the lawsuits challenged the validity of the EEOC ruling. Press coverage mediated the effects of lawsuits. Figure 2 shows that in our sample, the proportion of firms with maternity leave policies rose dramatically between 1974 and 1977 . Compare this with figure 1, which 
American Journal of Sociology

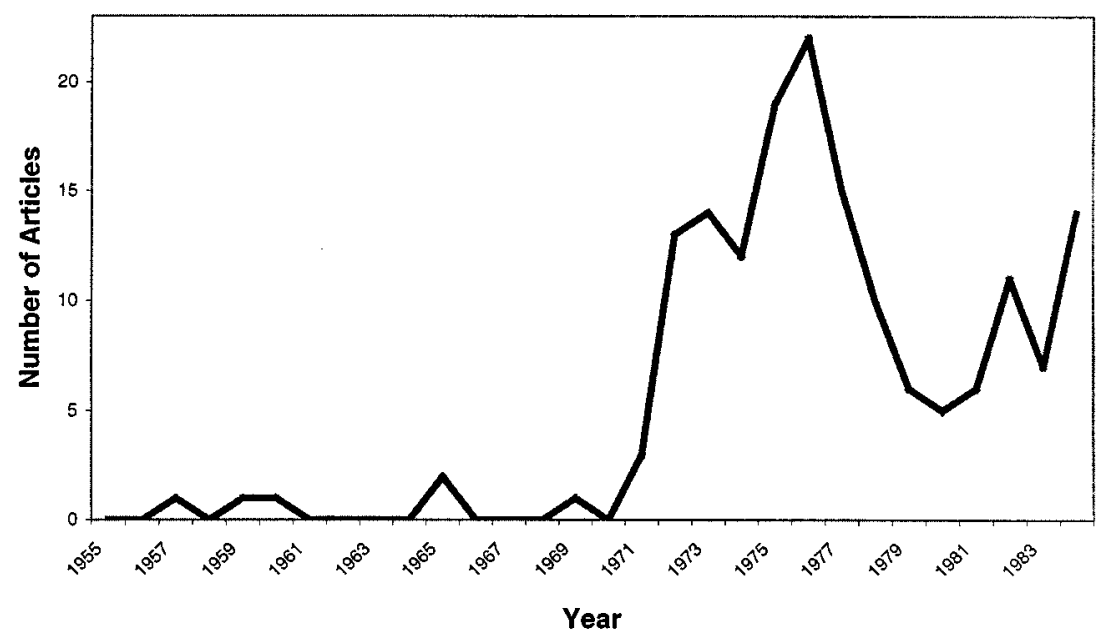

FIG. 1.-New York Times articles on maternity leave

shows press coverage of maternity leave. While it is important to exercise caution in interpreting figure 2, because changes over time may simply result from changes in covariates such as size, the correspondence between figures 1 and 2 during this period is suggestive. It appears that press coverage stimulated employers to adopt maternity leave. There were few suits

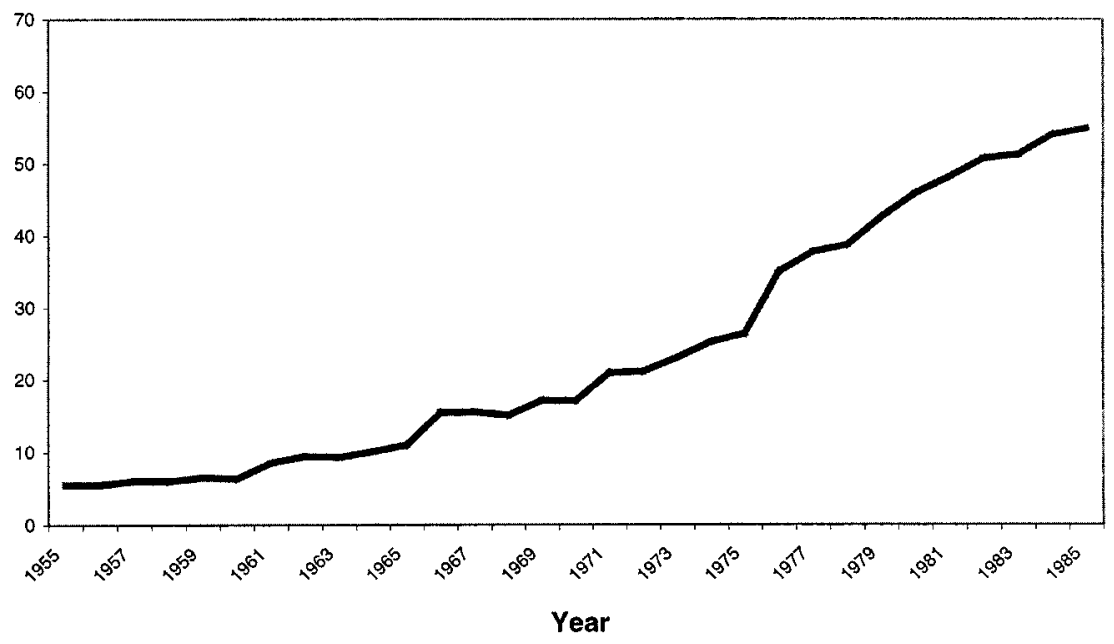

FIG. 2.-Percentage of employers with maternity leave 
in these early years, thus, as we argue below, employers responded to publicity rather than to the actual risk of being sued.

HyPOTHESIS 2.-Press coverage of maternity leave regulations increases the likelihood an employer will adopt maternity leave policies.

The Pregnancy Discrimination Act of 1978: Congress's Equal Protection Mandate

After the Supreme Court struck down the EEOC ruling in 1976, Congress responded by writing the EEOC position into law in the Pregnancy Discrimination Act (PDA) of 1978. The PDA gives us the opportunity to compare the effects of an administrative ruling with those of a similar congressional act. The PDA amended the Title VII definition of "discrimination because of sex" to include discrimination "on the basis of pregnancy, childbirth, or related medical conditions." Like the EEOC ruling, the act depended on the principle of equal protection to require employers to treat women affected by pregnancy "the same for all employment-related purposes" as other persons "similar in their ability or inability to work" (United States Code 42: 2000e[k] [1994]). Employers would have to extend disability leaves and pay to cover pregnant women.

Employers did not challenge the PDA in court as they had challenged the EEOC guidelines, and as a consequence, the PDA received little press coverage. G.E. had argued that the EEOC's 1972 ruling misinterpreted congressional intent. Employers had no grounds to challenge the 1978 statute because Congress had made its intent clear therein. After a brief burst of press coverage, the PDA received little attention. While there had been 109 New York Times articles on maternity leave between 1972 and 1978, there were just 43 between 1979 and 1984 (see fig. 1). Most of those focused on new state and local maternity leave regulations.

Before 1978, the legal standing of the EEOC ruling was uncertain. Several courts found that Title VII of the Civil Rights Act required employers with disability benefits to offer matching maternity benefits. But G.E. continued to fight the case, and the Supreme Court found that Title VII required no such thing. Students of law and regulation predict that when a ruling is challenged in the courts, firms will delay compliance and await a resolution. If employers had awaited a final decision, then we would expect to see a slow increase in maternity leave policies after the EEOC ruling, followed by a rapid increase after the PDA. Instead, we expect that wide press coverage of G.E.'s challenge of the EEOC ruling led many employers to create maternity leave programs before the PDA settled the legal issue. Under our scenario, adoption rates would be high in the mid1970s. The Pregnancy Discrimination Act may have led firms to liberalize existing maternity leave programs (Vogel 1993) and encouraged feminists 
to fight for broader family leave laws (Elving 1995), but we expect that the law spawned few new corporate maternity leave programs. In resolving the legal issue, the PDA had the effect of curtailing public discourse on maternity leave.

It is important to note that studies of the spread of other corporate equal opportunity practices do not find a slowdown during the 1980s, after the Reagan administration reduced enforcement of Civil Rights laws. Employers continued to adopt affirmative action offices (Edelman 1992; Dobbin and Sutton 1998), formal grievance procedures to intercept discrimination complaints (Sutton et al. 1994; Sutton and Dobbin 1996), and formal hiring and promotion practices to prevent discrimination by middle managers (Dobbin et al. 1993). Yet we predict that publicity surrounding the G.E. case had led most employers who monitor the legal environment to install maternity leave policies by the late 1970s. A contested administrative ruling had caused susceptible employers to change their practices, so the new statute had limited effects.

Нуротнеsis 3.-Because many employers established maternity leave programs following the EEOC guidelines of 1972, we expect that the Pregnancy Discrimination Act will have little effect on employer adoption of maternity leave programs.

California's Maternity Leave Legislation of 1978: The Affirmative Action Approach

Some states went a step further than Congress, requiring all employers to offer job-protected maternity leave. California, in a 1978 amendment to the state Fair Employment and Housing Act (California Government Code 12945 [1998]), required employers with 15 or more workers to allow women to take maternity leaves. Unlike the PDA, the California law did not state that maternity leave provisions should match disability leave benefits. Instead it required all but the smallest of employers to allow jobguaranteed maternity disability leaves of up to four months, regardless of their treatment of other disabilities. For example, even if an employer only held a worker's job for four weeks after a heart attack, the employer would be required to hold a woman's job for 16 weeks if she was unable to work because of pregnancy or recovery from childbirth. Whereas the PDA was based on the principle of equal opportunity, the California law was based on the principle of affirmative action-it was designed to improve opportunities for a particular protected group.

While the issue of affirmative action in employment has generated a great deal of heat, scholarship has as yet generated little light on its relative efficacy. Previous labor market studies have compared sectors subject to equal opportunity law to those additionally subject to affirmative action 
law (Ashenfelter and Heckman 1976; Leonard 1984). Black men made bigger inroads in the latter group than in the former. We employ a similar method to examine the effects of these two approaches on employer practices.

We hypothesize that California's affirmative action law was more effective than the federal equal treatment law. History has produced a straightforward test. By 1978, the PDA required that maternity leaves and pay match disability leaves and pay. This law applied to employers in all 50 states. The California employers in our sample were, additionally, required by that state's affirmative action law to offer maternity leaves. Thus, in comparing California employers to those in New Jersey and Virginia after the 1978 legislation, we have a clear test of the effect of adding an affirmative action requirement to an equal treatment requirement.

Like the EEOC regulations, the California law received some press coverage upon passage and more attention during the course of legal challenges. A Los Angeles Times editorial encouraged passage in August of 1978 , and an article in the same paper announced passage on September 30, 1978. Employers challenged the law in 1982, claiming that it conflicted with the equal treatment principle of the Pregnancy Discrimination Act (California Federal Savings and Loan Association v. Guerra, 107 Sup. Ct. 683 [1987]). In the 1987 Supreme Court decision upholding the California law, Thurgood Marshall argued that the Pregnancy Discrimination Act was intended to create "a floor beneath which pregnancy disability benefits may not drop-not a ceiling above which they may not rise" (quoted in Vogel 1993, p. 88; see also Rhode 1989). The case received considerable national coverage; five of the New York Times articles on maternity between 1982 and 1984 (see fig. 1) covered it.

Feminists held different positions on the wisdom of the affirmative action approach, and the public debate helped to make employers aware of the California law (Gorney 1984; Rhode 1989). Some feminists opposed what they derogatorily referred to as the "special treatment" approach of the California law, drawing comparisons to paternalist legislation from the turn of the century that had limited women's employment opportunities (see Kessler-Harris 1982; McCammon 1996). Many mainstream organizations that had fought for gender equality - the National Organization of Women, the League of Women Voters, the National Women's Political Caucus, and the American Civil Liberties Union-sided with California employers in opposing that state's law (Vogel 1993, p. 78). These groups advocated the approach that would later become law in the Family and Medical Leave Act, of guaranteeing leaves to new fathers as well as new mothers. When the United States District Court overturned California's maternity leave law in 1984, Dianne Feinstein, San Francisco's Democratic mayor, praised the court, arguing, "What we women have been 


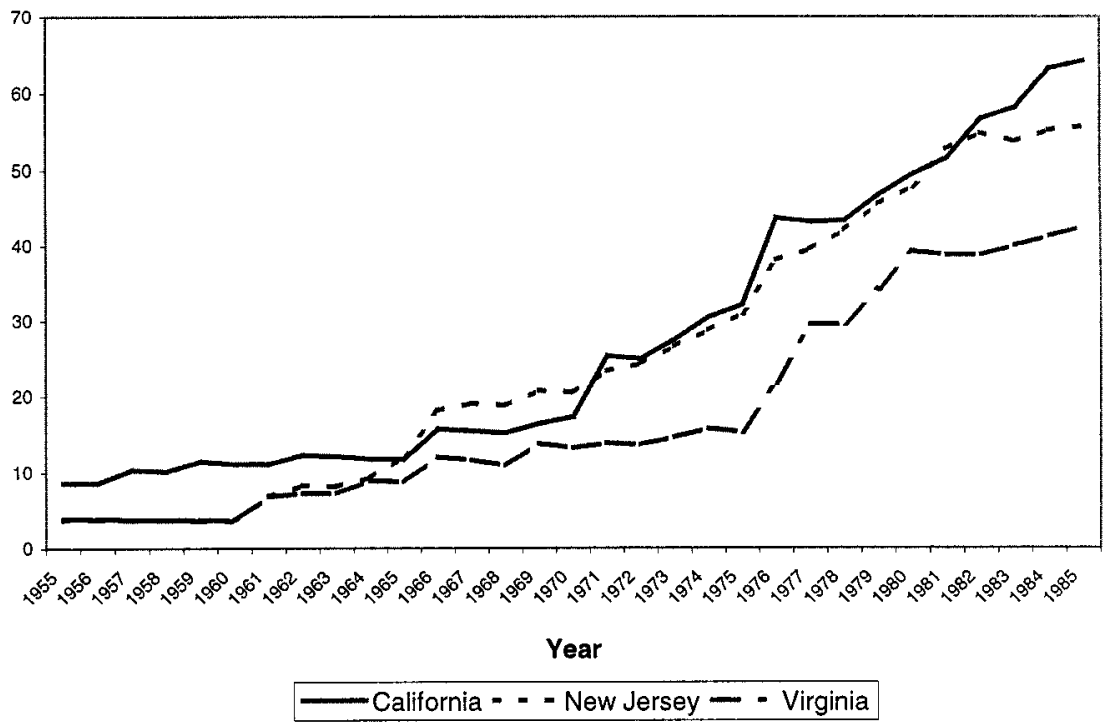

FIG. 3.-Percentage of employers with maternity leave by state

saying all along is we want to be treated equally. Now we have to put our money where our mouth is. What we were asking was to create a special group of workers that in essence is pregnant women and new mothers. I just don't happen to agree with that" (UPI 1984, p. 5). Others argued that because women bear the brunt of pregnancy, requiring equal treatment did not do enough to equalize opportunity for women. These feminists saw California's law as a more realistic way to help advance women's employment opportunities.

We predict that California's affirmative action law had a net positive effect on employers. In figure 3 , we present the prevalence of maternity leave, both over time and by state. By about 1980, the diffusion of maternity leave policies had stalled among New Jersey and Virginia employers but not among California employers. Others have found that state-level employment statutes do shape workplace practices (e.g., Guthrie and Roth 1999).

Hypothesis 4.-Following the maternity leave requirements of the 1978 law, employers in California will adopt maternity leave at higher rates than employers in New Jersey or Virginia.

\section{THEORIES OF FRINGE BENEFITS}

The conventional wisdom, as sketched above by Bob Dole and the Chamber of Commerce, comes from labor economists, who suggest that employ- 
ers responded to the growing ranks of women in the labor market with maternity leave programs. We examine this thesis by looking at industry feminization and change in feminization. A second important argument comes from students of law and regulation, who suggest that employers comply with laws in direct proportion to the risk of sanction. We examine this thesis by comparing a congressional statute of sure legal standing with an administrative ruling that was being challenged in the courts. We also examine the risk of legal sanction with a measure of maternity leave cases in federal courts.

Quite a few scholars have studied employer work/family policies in general and maternity leave in particular, although none has studied the spread of maternity leave over time (Glass and Fujimoto 1995; Goodstein 1994; Guthrie and Roth 1999; Ingram and Simons 1995; Milliken et al. 1998; Osterman 1995). Drawing on these studies, we review other factors that have affected human resources practices and work/family policies in particular.

\section{The Feminization Thesis}

Labor economists argue that employers use benefits to compete for labor and tailor benefits to labor market characteristics. A number of analysts have sought to show that industry feminization predicts employer work/ family benefits. Cross-sectional studies have produced mixed results. Goodstein (1994) and Osterman (1995) find that employers with large numbers of women are more likely to offer work/family benefits, and Guthrie and Roth (1999) find that employers in industries with large numbers of women are more likely to offer paid maternity leave. But Glass and Fujimoto (1995) found that employers with large numbers of women are not more likely to have maternity leave, and Ingram and Simons (1995) find that such employers are no more likely to offer an array of work/family benefits, including maternity leave. Previous cross-sectional studies have not examined whether trends in feminization matter. If labor economists are correct, we should find that industry feminization predicts maternity leave adoption and that change in feminization also predicts adoption.

НyротHESIS 5.-Employers in sectors with high proportions of women workers, and those in sectors where women's representation is growing, will adopt maternity leave to compete in the labor market.

\section{The Risk of Sanction Thesis}

Students of regulation from both the left and right have made economistic arguments about how firms respond to the law. Richard Posner, a founder 
and prolific proponent of the school of law and economics, suggests that firms are rational actors when dealing with the law (Posner 1974, 1997). When faced with a law, they calculate the costs of compliance and noncompliance. As the risk of legal sanction increases, so should the calculated cost of noncompliance. Some students of regulation from the left, such as Cass Sunstein $(1990,1996)$, advocate a similar approach to the issue of compliance as well. Agents comply with the law in proportion to the perceived risk of sanction.

Based in economic arguments about behavior, these perspectives suggest hypotheses about employer compliance with maternity leave law. First, they suggest that employers should have been more likely to create maternity leave programs after passage of the PDA, which had certain legal standing, than after the EEOC ruling, which had uncertain legal standing and was in fact struck down by the Supreme Court.

Hyротнеsis 6.-Because the legal standing of the EEOC guidelines was uncertain and the standing of the PDA was not, employers awaited the latter before creating maternity leave policies.

Second, employers should have adopted maternity leave in direct response to the rising risk of being sued. Figure 4, which charts the number of federal court decisions in maternity leave cases, shows the increased risk of litigation faced by employers. While a few high-profile lawsuits dominated the media in the early and mid-1970s, the number of suits was small. Litigation increased after press coverage rose and remained high

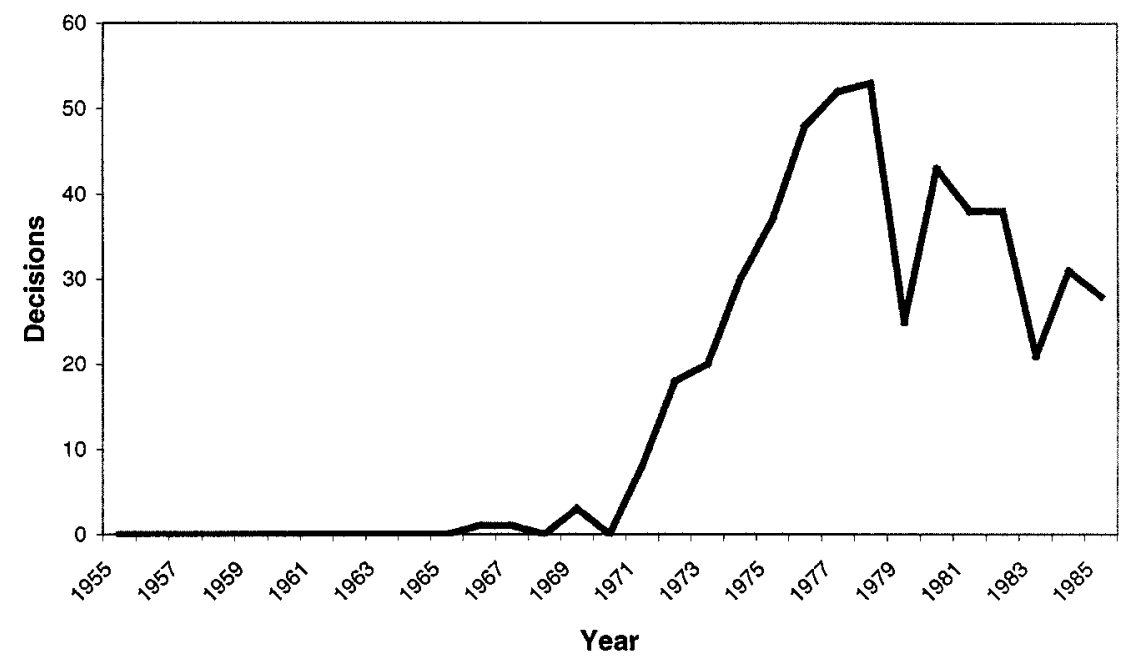

FIG. 4.-Federal court decisions in maternity leave cases 
after the Pregnancy Discrimination Act and during the Reagan era. In his study of pregnancy discrimination in the United States, Mark Edwards argues that this litigation led employers to change their maternity leave practices. He claims litigation "directly forced employers to accommodate pregnancy in the workplace" (1996, p. 251). We examine whether there is a direct effect of litigation. Previous studies suggest that the risk of litigation affected employer maternity leave practices even after passage of the FMLA. In a study of corporate maternity pay in 1996, Guthrie and Roth (1999) show that employers in liberal federal circuit court districts are more likely to offer pay. We test the hypothesis that the risk of litigation stimulated the spread of maternity leave.

HyPOTHESIS 7.-The risk of litigation, as measure by an annual count of federal court decisions in maternity leave cases, increases the likelihood an employer will adopt maternity leave.

Neoclassical and Transaction Cost Economics: Recruitment and Retention

Economists offer several relevant hypotheses, beyond the feminization thesis, that concern how employers use fringe benefits to attract and retain workers. Firms are thought to provide better benefits when labor markets are tight and when turnover is particularly costly.

There is some evidence that employers are more likely to adopt maternity leave and other family benefits in tight labor markets. Glass and Fujimoto (1995) find that employers with large numbers of professional and managerial workers-two groups with low unemployment rates-are more likely to offer maternity pay but no more likely to offer job-guaranteed leaves. Goodstein (1994) and Ingram and Simons (1995) find that industry-level scarcity of female workers leads employers to offer work/ family benefits such as maternity leave, but Osterman (1995) finds that employers with recruitment and retention problems are no more likely to have work/family policies.

Hyротнеsis 8.-Employers in sectors with low unemployment rates, and in sectors with declining unemployment rates, will be more likely to adopt maternity leave.

Labor economists and transaction costs theorists expect employers who depend on firm-specific skills, such as those in capital-intensive industries, to offer benefits that bind workers to the firm (Doeringer and Piore 1971; Williamson 1981). Sociologists and economists have found that firms in the finance sector also depend on long-term employment, and these employers also use personnel practices and fringe benefits to tie workers to the firm (Goldin 1986; Baron, Jennings, and Dobbin 1988; Milliken et al. 1998). 
American Journal of Sociology

HyPOTHESIS 9.-Industries that value long-term employment will be more likely to adopt maternity leave policies.

Labor segmentation theorists have made kindred arguments about employer efforts to retain workers through "bureaucratic control" systems, which formalize promotion and expand retention-related benefits (e.g., pensions and leaves) to encourage workers to stay with the firm (Edwards 1979; Gordon, Edwards, and Reich 1982). Guthrie and Roth (1999) find that employers with formalized personnel systems are more likely to offer paid maternity leave.

HyPOTHESIS 10.-Employers with formal internal labor market practices will be more likely to adopt maternity leave.

\section{Neoinstitutional Theory: Professional Groups and Public Visibility}

Neoinstitutional studies have established that professionals often determine corporate response to unclear policy mandates (Edelman et al. 1992; Sutton and Dobbin 1996, p. 795). Personnel and legal experts have promoted a range of different Civil Rights compliance mechanisms. Benefits specialists were in charge of leave policies, and so they were most likely to have monitored legal developments in this area.

НуротHESIS 11.-Organizations with personnel, legal, and benefits offices will be more likely to adopt maternity leave policies.

Studies have also shown that public sector and nonprofit organizations are more susceptible to normative pressures regarding fair employment practices (Meyer and Scott 1983; Dobbin et al. 1988; Edelman 1990). In an analysis of cross-sectional data from 1991, Ingram and Simons (1995) confirm that public-sector employers are more likely to offer work/family benefits, including leaves, dependent care assistance, and flexible work schedules.

HyPOTHESIS 12.-Public and nonprofit organizations will be more likely than private sector firms to adopt maternity leave policies.

\section{Industrial Relations: Union Pressure}

Unions have historically fought for generous fringe benefit packages (Freeman 1981; Freeman and Kleiner 1990; Kalleberg and Van Buren 1996), but studies find little evidence that unionization is associated with leave policies (Osterman 1995; BNA 1986). We control for unionization.

HyPOTHESIS 13.-The presence of a union will increase an employer's likelihood of adopting maternity leave.

Unions in feminized sectors have often pushed for benefits favored by women (Milkman 1987, p. 2; Schatz 1983). Glass and Fujimoto (1995) find that unionization and an interaction term between unionization and 
feminization show positive effects on organizational maternity leave, suggesting that unions fight for maternity leave when their members are women.

Hyротнеsis 14.-Unionization will have a particularly strong effect in feminized industries.

\section{Size and Age}

Scale should predict the formalization of maternity policies, as it predicts the formalization of many other policies (Blau and Schoenherr 1971; Kalleberg and Van Buren 1996). Most studies show that size has a nonlinear effect, because an increase of 100 employees has a greater impact on a firm of 50 than on a firm of 1,000.

Hypothesis 15.-Size will have a positive, but declining, effect on the likelihood employers will adopt maternity leave policies.

Older organizations should be less likely to adopt maternity leave. Stinchcombe (1965) discovers that organizations find it difficult to change established practices. Selznick (1957) likewise argues that, over time, organizations become resistant to change.

HyPOTHESIS 16.-Older organizations will be less likely to adopt maternity leave.

\section{DATA AND METHODS}

\section{Sample and Data Collection}

We analyze data collected from a stratified random sample of public, nonprofit, and private sector establishments in 1985-86. Retrospective data on the history of each establishment's personnel policies were collected from 279 respondents. These respondents were located in three states, selected for their varying legal environments: California, New Jersey, and Virginia. The sample was stratified by industry to ensure variety and to facilitate examination of industry effects. Establishments were sampled from banking, chemical manufacturing, electrical manufacturing, machinery manufacturing, publishing, transportation, retail trade, hospitals, nonprofit organizations, and city, county, state, and federal agencies. We used the best population list available for each group and omitted employers with fewer than 50 workers and employers who reported that they did not operate in one of the states or in one of the industries sampled (Dobbin et al. 1993; Sutton and Dobbin 1996). The survey covered organizational structure and demographics and key employment policies for the period $1955-85$. We obtained a response rate of $48 \%$, but after eliminating 21 responses due to the poor quality of the data, we were left with a net 
rate of $45 \%$. This compares favorably with the response rates obtained in other organizational studies. Milliken et al. (1998) report a rate of 18\%; Lincoln and Kalleberg (1985) report 35\%; Blau et al. (1976) report 36\%; Edelman (1992) reports 54\%; and the National Organizations Survey for 1991 reports 65\% (see Spaeth and O'Rourke 1996, p. 32). We expect that there is some response bias in the data, in that establishments with personnel offices were probably more likely to participate. As such establishments may be more likely to create maternity leave policies, we suspect that our over-time plots somewhat overstate the prevalence of maternity leave. This bias is unlikely to affect the event history analyses, however. First, the survey includes information on the factor most likely to create response bias, the presence of a personnel office, and, hence, we can include that factor in the model. Second, we have many organization-byyear spells without personnel offices, and so we have adequate variance on this covariate.

The data were transformed into annual spells, yielding a data set with 4,921 at-risk organization-years. Each annual spell records values for the outcome and for independent variables for each year. We retained a record for each year in which an organization was operating and at risk of maternity leave adoption. We removed the organization-year spells in which each organization was not at risk of adopting maternity leavethose spells before the organization's birth and those after it had created a leave policy. Organizations that did not adopt maternity leave before 1986 are included for the whole period. Our analysis relies on the 4,726 at-risk organization-years with complete data for the relevant variables.

\section{Measures and Model Specification}

Maternity leave policy adoption.-Survey respondents were asked whether their organization had ever had a formal policy covering maternity leave. As noted above, organizations remain in the risk set until adoption of maternity leave or censoring, in 1985. We do not have information on whether the leave policies provide pay or on the length of leave. For organizations with policies, respondents were asked when the policy was adopted and when, if ever, it was abandoned. Formal policies covering maternity leave serve as an important resource for women. For the most part, the policies adopted in the 1970s and early 1980s replaced formal or informal policies of requiring pregnant workers to resign (Fryburger 1975; O'Connell 1990). The job guarantee fosters career continuity, and this has positive long-term effects on women's advancement and income (Waldfogel 1997; Jacobsen and Levin 1995).

Independent variables. - Table 1 lists the independent variables. These vary over time, and they were collected at the establishment level unless 
TABLE 1

VARIables UsEd IN ANALysis

\begin{tabular}{|c|c|c|}
\hline Variable & Description & $\begin{array}{l}\text { Predicted } \\
\text { Effect }\end{array}$ \\
\hline \multicolumn{3}{|l|}{ Organizational characteristics: } \\
\hline 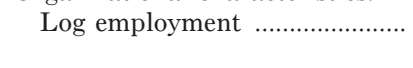 & $\begin{array}{l}\text { Natural logarithm of number of employ- } \\
\text { ees in previous year }\end{array}$ & + \\
\hline Age .......... & Years since organization's founding & - \\
\hline 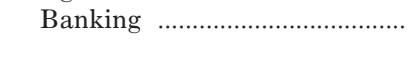 & $\begin{array}{l}\text { Binary variable marking sector-does not } \\
\text { change over time }\end{array}$ & + \\
\hline Core manufacturing ….................. & $\begin{array}{l}\text { Chemicals, electrical manufacturing, and } \\
\text { machinery manufacturing }\end{array}$ & + \\
\hline Government agencies ............... & $\begin{array}{l}\text { Federal, state, county, and local govern- } \\
\text { ment }\end{array}$ & + \\
\hline Unionization . & $\begin{array}{l}\text { Binary variable for presence of union con- } \\
\text { tract in previous year }\end{array}$ & + \\
\hline Personnel office .......... & $\begin{array}{l}\text { Binary variable for presence of personnel } \\
\text { office in previous year }\end{array}$ & + \\
\hline 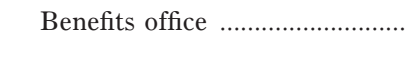 & $\begin{array}{l}\text { Binary variable for presence of benefits of- } \\
\text { fice in previous year }\end{array}$ & + \\
\hline 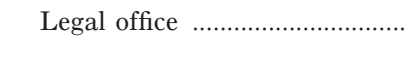 & $\begin{array}{l}\text { Binary variable for presence of legal of- } \\
\text { fice in previous year }\end{array}$ & + \\
\hline Formalization scale …................... & $\begin{array}{l}\text { Scale (1-5) marking presence of job lad- } \\
\text { ders, written job descriptions, salary } \\
\text { classification system, nonunion griev- } \\
\text { ance procedure, and performance evalu- } \\
\text { ations in previous year }\end{array}$ & + \\
\hline \multicolumn{3}{|l|}{ Labor market factors: } \\
\hline 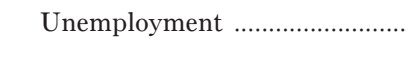 & $\begin{array}{l}\text { Regional unemployment rate in previous } \\
\text { year }\end{array}$ & - \\
\hline Change in unemployment & Change in regional unemployment & - \\
\hline 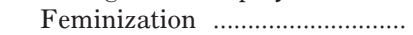 & Industry feminization in previous year & + \\
\hline Change in feminization ............. & Change in industry feminization & + \\
\hline \multicolumn{3}{|l|}{ Legal and press attention: } \\
\hline 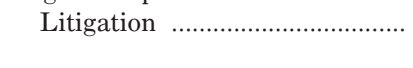 & $\begin{array}{l}\text { Federal decisions in maternity leave cases } \\
\text { (three-year moving average) }\end{array}$ & + \\
\hline Press coverage …….................... & $\begin{array}{l}\text { New York Times articles on maternity } \\
\text { leave (three-year moving average) }\end{array}$ & + \\
\hline \multicolumn{3}{|l|}{ Policy environment: } \\
\hline 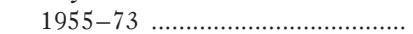 & Reference period & \\
\hline $1974-79$ ………………… & Period following EEOC guidelines & + \\
\hline 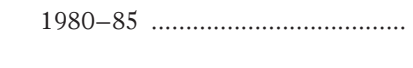 & $\begin{array}{l}\text { Period following Pregnancy Discrimina- } \\
\text { tion Act }\end{array}$ & (none) \\
\hline California . & $\begin{array}{l}\text { Reference states are New Jersey and } \\
\text { Virginia }\end{array}$ & (none) \\
\hline 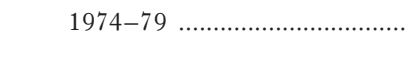 & $\begin{array}{l}\text { Additional effects of period following } \\
\text { EEOC guidelines, in California }\end{array}$ & (none) \\
\hline 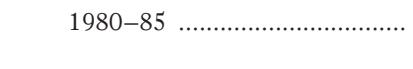 & $\begin{array}{l}\text { Period following California's affirmative } \\
\text { action law }\end{array}$ & + \\
\hline
\end{tabular}

NoтE.-Variables are subject to change over time. Reference industries include nonprofit organizations, hospitals, publishing, transportation, and real estate. 
noted. To measure establishment size, we requested figures on the number of employees in 1985, 1975, 1965, and 1955. We also asked about years in which unusual gains or losses occurred. Annual size figures were interpolated from these responses and logged for use in the models. To measure age, we collected information on the founding date of each organization. We measure firm-specific skills with industry variables. Previous studies show that among the industries in our sample, chemicals, electrical machinery, and machinery manufacturing have high levels of firm-specific skills (Gordon, Edwards, and Reich 1982). We include these three industries in core manufacturing. We also include banking and government variables to test the hypotheses that concern for long-term employment and vulnerability to state and public pressures increase adoptions of maternity leave. We use a binary variable that represents the presence of a union contract. To measure formalization, we include a scale comprised of five internal labor market (ILM) practices: job ladder, written job description, salary classification, nonunion grievance procedure, and formal performance evaluation. We measure the presence of legal, personnel, and benefits offices with binary variables.

We supplement the survey data with publicly available data on labor market characteristics. To measure the proportion female in each industry, we use data from the Bureau of Labor Statistics' Current Employment Statistics (CES) Survey, which provides annual figures on female employment at the two-digit Standard Industrial Code (SIC) level. CES is the only source of labor force data that covers feminization before 1964, and it provides a more detailed industry breakdown than the other possible sources, such as the early Current Population Survey and the Equal Employment Opportunity Commission annual reports. For a few industries, we estimated figures for several missing years using simple linear regression. ${ }^{3}$ Most missing data were from 1955-57, when there was little annual change in female labor force participation. In addition to proportion female, we use a lagged change score. While we would like to include an establishment-level measure of feminization as well, questions on workforce composition were deleted from the survey instrument after a pretest showed a high rate of refusals for questions about female employment.

To measure unemployment, we use regional unemployment rates calculated from the Current Population Survey. We use regional data rather

${ }^{3}$ The estimated years are 1955-57 (chemicals, publishing); $1955-58$ (electrical, machinery, hospitals, retail trade); 1955-62 (banks, transportation, government); and 1955-71 (nonprofit organizations). 
than state-level data, because these data are available for the entire period. We use both the unemployment rate and a change score.

To measure press attention, we use a lagged three-year average of the number of New York Times articles dealing with maternity leave. The New York Times is cataloged in the New York Times Index and in the Lexis-Nexis service. These sources made identifying and counting maternity leave articles feasible, whereas other papers and magazines are not well indexed for the entire period covered by our study. We also estimated models using a lagged annual count of articles, and the results were substantially similar.

To measure litigation activity, we use a lagged three-year average of the number of federal court decisions in cases dealing with maternity leave. We gathered annual count data from the Lexis legal research service, using the GENFED, NEWER libraries to search all federal cases since 1944. We also collected annual counts of decisions in cases related to pregnancy discrimination. We estimated models using a lagged count of maternity leave cases, a lagged count of maternity leave and pregnancy discrimination cases, a lagged count of pregnancy discrimination cases, and a three-year average of pregnancy discrimination cases. Results were substantially similar, hence, we report models that use the lagged threeyear average of maternity leave cases.

To measure the effects of public policies, we include binary variables for the periods 1974-79 and 1980-85 (with 1955-73 omitted), a binary variable for operation in California, and an interaction between California and each period variable. We lag the periods one year, beginning each in the January following the first full year of operation of the new policy. We expect that the contentious legal environment, prompted by changes in the EEOC guidelines, will increase adoption among all employers between 1974 and 1979. We also hypothesize that the federal Pregnancy Discrimination Act, which required equal treatment of pregnancy and other disabilities, will not increase the adoption of formal maternity leave policies in New Jersey and Virginia in the period 1980-85. We expect that California's maternity leave requirement, added to its state fair employment law late in 1978, will increase adoptions in that state between 1980 and 1985. Thus, we expect that, with 1955-73 as the reference period, the period 1974-79 will have a positive effect, and the period 1980-85 will have little or no effect. We expect to find that California was no different from New Jersey and Virginia before 1980 and thus do not expect to see significant coefficients for California or for California, 1974-79. However, we expect the interaction of California with 1980-85 to have a positive effect as a consequence of the state's maternity leave law. 


\section{Estimation}

We use discrete event-history methods because we do not know the exact timing of adoption within the spells and because we have many "tied" events, that is, years in which multiple employers adopt maternity leaves (Kalbfleisch and Prentice 1980; Allison 1995, pp. 220-22). In particular, we employ discrete models where the hazard (instantaneous risk) at time $t$ for an organization with characteristics $i$ is

$$
h\left(t \mid X_{i}\right)=h_{0}(t)^{\left(X_{i}^{\prime} \beta\right)} .
$$

Here, $h_{0}(t)$ is a baseline hazard function describing the risk for organizations with baseline characteristics $X=0$, and the exponentiate $\left(X_{i}^{\prime} \beta\right)$ is a proportionate increase or reduction in risk associated with characteristics $X_{i}$.

Because the transformed data set contains annual spells, the hazard of adoption in each year is equivalent to $P_{\text {it }}$, the conditional probability that the event occurs to organization $i$ in year $t$, given that it has not already occurred. We model the complementary log-log transformation of the survival function $\left(1-P_{\mathrm{it}}\right)$ on the covariates, specified for that time: ${ }^{4}$

$$
\log \left[-\log \left(1-P_{\mathrm{it}}\right)\right]=\alpha(t)+\beta^{\prime} X_{\mathrm{it}} .
$$

The coefficients estimated by this procedure have a proportional hazards, or relative risk, interpretation. We estimated the models using a maximum likelihood method, carried out with the GENMOD procedure in the statistical program SAS.

We present three nested models predicting maternity leave adoption. First, we examine the effects of organizational and labor market variables. Second, we add variables representing maternity leave litigation and press coverage. Third, we add variables representing changes in the legal environment. In models not reported here, we added a time trend to rule out the possibility that the legal regime variables are picking up a simple secular change. They are not.

\section{FINDINGS}

We find little support for the feminization and legal sanction hypotheses and strong support for neoinstitutional hypotheses. First, employers responded to press coverage of changes in maternity leave law. Second, in

\footnotetext{
${ }^{4}$ The complementary log-log transformation takes a variable with the values between 0 and 1 and changes it to a continuous value that ranges from minus infinity to plus infinity (Allison 1996, p. 216).
} 
the contentious legal environment that followed the EEOC guidelines, employers adopted maternity leave in large numbers; whereas after the Pregnancy Discrimination Act confirmed the legal standing of the EEOC position, employers were less likely to adopt maternity leave. We conclude that the contested administrative ruling caused susceptible employers to change their practices and that the congressional statute thus had no net effect. This supports our hypothesis about the paradoxical power of putatively weak administrative rulings and undermines the legal sanction hypothesis about the relative power of congressional statutes. Another test of the legal sanction hypothesis also fails: maternity leave litigation does not show a significant effect on employer policies. Our third finding about the legal environment is that California's affirmative action law was more effective than the federal equal protection law, as expected. In fully specified models, we found no support for the feminization thesis: industrylevel feminization, and change in feminization, failed to show significant effects.

Our most striking findings can be seen by comparing models 1,2 , and 3 in table 2. To test the feminization hypothesis, we examine the sex composition of the workforce at the industry level. Whereas in model 1, both feminization and change in feminization showed significant effects, in models 2 and 3, in which we control for press coverage of maternity leave laws and for the laws themselves, the feminization measures are no longer significant. These findings support cross-sectional studies showing that feminization has little effect on maternity leave (Ingram and Simons 1995; Glass and Fujimoto 1995). To be sure, female workforce participation was rising in the 1970s when maternity leave policies began to diffuse, but it appears that legal shifts better predict organizational change. Because maternity leave was covered under sex discrimination law, an industry's particular sex composition is relatively unimportant as a predictor of adoption. It appears that employers adopted maternity leave not to compete for women workers so much as to comply with the law. This can be seen, indirectly, in figure 2-few employers, even those in feminized industries offered maternity leave before the law changed. It was not workforce feminization per se that spawned maternity leave policies.

We test the legal sanction hypothesis by comparing the effects of the PDA to those of the EEOC guidelines, and as noted above, the PDA did not show a net effect. We conclude that the EEOC guidelines had led employers who were attentive to the law to change their practices. We also test the legal sanction hypothesis by looking at maternity leave litigation counts. The litigation variable does show a positive effect in the presence of controls (in a model identical to model 2 but without the press count variable), but the press count variable washes that effect out. This is not surprising, for we saw the conjunction of the peak of press coverage (fig. 
TABLE 2

Estimates of the Adoption of Maternity Leave

\begin{tabular}{|c|c|c|c|c|c|c|}
\hline \multirow[b]{3}{*}{ Log employment ……………..... } & \multicolumn{6}{|c|}{ MODEL } \\
\hline & \multicolumn{2}{|c|}{$\begin{array}{l}\text { Organizational } \\
\text { and Labor } \\
\text { Market Variables } \\
\text { (1) }\end{array}$} & \multicolumn{2}{|c|}{$\begin{array}{c}\text { With Press } \\
\text { and Litigation } \\
\text { Variables } \\
\text { (2) }\end{array}$} & \multicolumn{2}{|c|}{$\begin{array}{l}\text { With Legal } \\
\text { Periods } \\
\text { (3) }\end{array}$} \\
\hline & $.128 *$ & $(.063)$ & $.146 *$ & $(.064)$ & $.146^{*}$ & $(.064)$ \\
\hline Age & $-.004^{*}$ & $(.002)$ & $-.004 *$ & $(.002)$ & $-.004 *$ & $(.002)$ \\
\hline 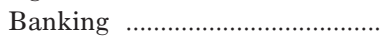 & $1.231 * *$ & $(.287)$ & $1.254 * *$ & $(.287)$ & $1.197 * *$ & $(.289)$ \\
\hline Core manufacturing …….............. & $1.200 * *$ & $(.271)$ & $1.138 * *$ & $(.269)$ & $1.036^{* * *}$ & $(.271)$ \\
\hline Government agencies ................... & $.620 *$ & $(.259)$ & $.639 *$ & $(.258)$ & $.622 *$ & $(.260)$ \\
\hline Unionized .................................. & .196 & $(.228)$ & .146 & $(.230)$ & .049 & $(.236)$ \\
\hline Personnel office & .182 & $(.218)$ & .163 & $(.216)$ & .193 & $(.214)$ \\
\hline 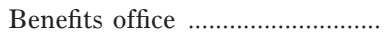 & $.545 *$ & $(.212)$ & $.513 *$ & $(.212)$ & $.554 *$ & $(.218)$ \\
\hline 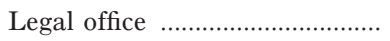 & -.039 & $(.242)$ & .021 & $(.245)$ & .069 & $(.248)$ \\
\hline Formalization scale & .080 & $(.063)$ & .062 & $(.064)$ & .058 & $(.064)$ \\
\hline 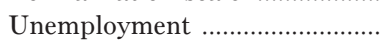 & $.265 * *$ & $(.056)$ & $.208 * *$ & $(.069)$ & .050 & $(0.83)$ \\
\hline Change in unemployment ........ & -.085 & $(.075)$ & -.001 & $(.079)$ & -.060 & $(.085)$ \\
\hline 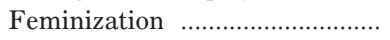 & $.014^{*}$ & $(.006)$ & .012 & $(.006)$ & .009 & $(.006)$ \\
\hline Change in feminization .............. & $8.669^{*}$ & $(3.496)$ & 7.247 & $(3.798)$ & 6.871 & $(4.084)$ \\
\hline \multicolumn{7}{|l|}{ Maternity leave: } \\
\hline 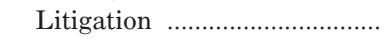 & & & -.037 & $(.019)$ & -.009 & $(.028)$ \\
\hline Press coverage ……................. & & & $.084 * *$ & $(.029)$ & -.006 & $(.044)$ \\
\hline 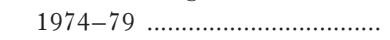 & & & & & $1.744 * *$ & $(.509)$ \\
\hline 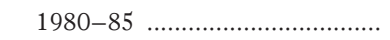 & & & & & .419 & $(.630)$ \\
\hline 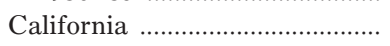 & & & & & .227 & $(.304)$ \\
\hline 1974-79 ……………............ & & & & & -.237 & $(.392)$ \\
\hline 1980-85 ………...................... & & & & & $1.233 *$ & $(.512)$ \\
\hline 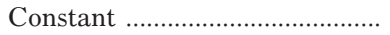 & $-7.331 * *$ & $(.604)$ & $-7.152 * *$ & $(.639)$ & $-6.273^{* *}$ & $=(.666)$ \\
\hline 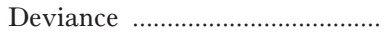 & 1,201 & & 1,185 & .99 & 1,162 & .09 \\
\hline 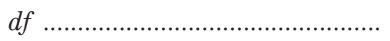 & 4,71 & & 4,70 & & 4,70 & \\
\hline
\end{tabular}

NotE.-SEs are in parentheses.

$* P<.05$.

$* * P<.01$.

1) and the rapid expansion of corporate maternity leave policies (fig. 2) in the mid-1970s. The volume of litigation (see fig. 4) rose when the legal standing of the EEOC position was confirmed by the PDA and remained high during the early 1980s. The spread of maternity leave slowed in this period. The results suggest that employers respond not to the objective risk of being sued but to press coverage that makes them aware of new legal standards.

After evaluating the indirect effects of legal changes, via press coverage, in model 2, we evaluate the direct effects of legal changes in model 3 . With other factors controlled, the annual hazard of adopting maternity 
leave is about 5.8 times higher in the period 1974-79 than in the period 1955-73. This suggests that the EEOC guidelines had a strong positive effect on the adoption of maternity leave. However, with full controls in the model, the coefficient for $1980-85$ is small and nonsignificant. This suggests that after the Pregnancy Discrimination Act of 1978 was passed, employers were no more likely to add maternity leave policies than they had been in the period 1955-73.

We introduce the variable California and interact it with the two latter periods to determine whether California's 1978 maternity leave law had a net effect on adoption. California (which captures the period 1955-73) and California, 1974-79, show small and nonsignificant effects, suggesting that before 1980s, California employers were no different from New Jersey and Virginia employers. However, California, 1980-85, shows a large and significant effect, which suggests that the 1978 affirmative action law had an impact. While New Jersey and Virginia employers were no more likely to adopt maternity leave in 1980-85 than they had been in 1955-73, California employers who had not already done so were about five times as likely to adopt leaves. To test whether California was different from both other states, we introduced a parallel set of period interactions for New Jersey (in a model not reported here). The results-a significant positive coefficient for California, 1980-85, and an insignificant coefficient for New Jersey, 1980-85-show that California was unique. ${ }^{5}$

In sum, models 2 and 3 measure shifts in the legal environment in different ways. In model 2, we observe the effects of legal changes as mediated by press coverage. In model 3 , we observe the effects of legal changes directly, with measures that capture each state-by-period policy environment. We do not expect to find that all measures are significant when included together. Press coverage does not show a significant effect in model 3, and we conclude that this is because the state-by-period interactions better capture the substantial variety in the law than does the press coverage variable.

Next, we turn to control variables. As expected, large employers are more likely to create maternity leave programs and older employers are

\footnotetext{
${ }^{5}$ After 1978, the combination of the Pregnancy Disability Act and state laws on temporary disability insurance meant that medium and large employers in both California and New Jersey were required to cover pregnancy in their disability programs (California Unemployment Insurance Code 2626 [1998], New Jersey Statutes 43:21-29 [1991]). Women in these states received some pay during their pregnancy-related absences, but these laws did not require job-guaranteed leaves per se. If state disability laws had been crucial to the spread of maternity leave, we would have seen California and New Jersey employers behave differently than Virginia employers. New Jersey employers did not jump to add formal leave policies after the PDA, pointing to the importance of California's affirmative action law.
} 
less likely to do so. We speculated that industries that place a premium on employment continuity-including core manufacturing (chemicals, electrical machinery, and machinery) and finance-would be more likely to adopt maternity leave. We find consistent positive effects of location in these sectors.

We predicted that government agencies and nonprofit organizations would be quick to comply with new Civil Rights laws. While nonprofits were no different from organizations in the reference industries, and hence are included in the reference category in reported models, government agencies were significantly different.

We test the industrial relations hypotheses that unions fight for fringe benefits and that feminized unions fight for maternity leave. We found that unionized employers were not more likely to adopt maternity leave, and in results not reported here, we found that feminized, unionized employers were not more likely to do so either. However, we do not consider these findings to be definitive, because the industry variables may be capturing the effects of unions. The failure of the unionization measures may also be the result of a process that has been described by Selznick (1969), Kochan, Katz, and McKersie (1986), and Swenson (1992), whereby nonunion firms copy the industrial relations systems of their unionized peers.

We predicted that employers with personnel, legal, and benefits offices would be more likely to adopt maternity leave policies. The presence of a benefits office increases the annual risk by about $70 \%$. Personnel and legal offices show no effects, apparently because the benefits profession led the charge to create maternity policies. In a search of professional journal indexes, we found that benefits journals carried 55 articles on maternity leave between 1970 and 1984-more than personnel, labor law, and executive management journals combined. The formalization scale shows positive, but nonsignificant, effects in each model. It appears that having a professional within the organization to advocate maternity leave, in the person of a benefits manager, is more important than having formalized personnel functions.

Economists expect that when unemployment is low in an industry, employers will offer benefits, such as maternity leave, to attract new workers and bind incumbents to the firm. Models 1 and 2 suggest, on the contrary, that when unemployment is high, employers adopt maternity leave. However, model 3, with legal periods controlled, suggests that this relationship is spurious. The oil crisis of the mid-1970s produced high unemployment, and this happened to coincide with the implementation of the EEOC ruling. When we control for this period, the unexpected positive effect of unemployment disappears. 


\section{CONCLUSION}

Why did so many American employers create maternity leave programs in the 1970s and 1980s, well before passage of the Family and Medical Leave Act of 1993? Politicians, business leaders, and scholars have pointed to the growing presence of women in the workforce. We argue that sex discrimination law was the driving force. As federal agencies and the courts elaborated the definition of sex discrimination under the Civil Rights Act, employers added maternity leave policies to move into compliance.

We build on an insight from neoinstitutional theory-that structural weaknesses do not prevent the U.S. state from shaping employer practices. Previous studies have explored the effects of Congress's use of ambiguous language in employment law. The ambiguity of the law can lead employers, uncertain what exactly is required of them, to create elaborate compliance measures. Legal ambiguity can thus lead to strong corporate response. We have examined the consequences of another seeming weakness of the federal state, the separation of powers. The constitutional separation of powers allows all three branches of government to make law, but it also invites private parties to contest the law. To assess the effects of this legal openness on employer compliance, we compare the most vulnerable kind of law with the least vulnerable kind of law. Administrative law is weakest because it can be challenged by case law, which can, in turn, be overruled by legislation. In consequence, congressional acts appear to be more stable and powerful than administrative rulings. History has provided us with an opportunity to test this idea against a competing idea-that administrative rulings can be effective precisely because their vulnerability invites legal challenges, which can serve to promulgate them.

Perhaps our most surprising finding is that an embattled administrative ruling of uncertain legal standing caused large numbers of employers to adopt maternity leave policies. The EEOC's 1972 Guidelines on Discrimination because of Sex were challenged by employers who argued that the agency had no authority to extend sex discrimination law to cover pregnancy. Employers won this battle in the Supreme Court, yet, in the meantime, press coverage of their challenge helped to make other employers aware of the law. By the time Congress reversed the Supreme Court and codified the EEOC position in the Pregnancy Discrimination Act of 1978, those employers who were susceptible to legal pressure had already changed their policies. In brief, legal challenges to an administrative ruling led employers to comply with the ruling. We would expect to find the same process at work in other realms of business regulation, because 
administrators and judges interpret the law in realms as diverse as antitrust and occupational safety, and because employers frequently use the courts to challenge those interpretations. Given the administrative branch's reluctance to monitor each and every workplace, organizations are likely to learn about new legal standards through press coverage of litigation. Minor administrative rulings can have large effects, then, even when they are eventually overturned by judges (see McCann 1994, 1998).

We find little evidence that employers adopted maternity leave in response to the objective risk of legal sanction. First, they were not more likely to comply with an uncontested congressional statute than with an embattled administrative guideline. Second, they were not sensitive to the number of federal maternity leave lawsuits. This does not mean that the law did not matter; it means that the law affected employer practice by creating a social standard and not simply by creating a calculable risk. The behaviorist assumptions underlying the law-and-economics approach suggest that agents make objective evaluations of the risk of sanction by observing what the state is doing. The sociological assumptions underlying both the neoinstitutional (Meyer and Rowan 1977; Meyer 1994; Scott 1995) and the network (White 1981; Granovetter 1985) approaches suggest that agents monitor the behavior of their peers. In this case, our findings suggest, their lookouts were benefits professionals who tracked emerging norms in the organizational field. Employers behaved as social actors, copying the behavior of others, rather than as rational calculators, making objective assessments of the risks associated with noncompliance.

In addition to examining the efficacy of administrative law, we compare the two kinds of Civil Rights law that govern employment: equal opportunity law and affirmative action law. We make a critical comparison between the federal Pregnancy Discrimination Act of 1978 and California's Fair Housing and Employment law, passed in the same year. The federal law requires employers who offer medical disability leaves to cover maternity; the California law requires employers to allow maternity leaves even if they do not offer medical disability leaves. We compare employers in New Jersey and Virginia, subject only to the federal equal opportunity law, to those in California, subject to the affirmative action law. California's affirmative action law has a significant net effect, observable in both the over-time plot and the event-history analysis. We expect the finding that affirmative action laws are more effective in changing employer practices to hold up in other settings, and indeed early labor market studies support this idea (Leonard 1984).

Some argue that affirmative action laws are not politically viable, and others argue that they can do more harm than good. In light of the effec- 
tiveness of these policies, these fears are exaggerated. First, while political backlash has led some states to curtail affirmative action in higher education, common affirmative action practices in employment, such as recruiting and mentoring programs for women and minorities, remain popular with the public (Steeh and Krysan 1996, p. 132; Taylor 1995). Moreover, the newest affirmative action law-the Americans with Disabilities Act of 1990, which requires that employers accommodate the disabled-also enjoys widespread support. Second, while some fear that "special treatment" laws can harm the intended beneficiaries, our findings suggest that group-specific policies, functioning in the context of equal opportunity law, can make the workplace more hospitable for women. Recent evidence shows that paid maternity and parental leaves-expensive programs benefiting primarily women workers-have not limited women's employment in Europe (Ruhm and Teague 1997, pp. 147-48).

Public policy played an important role in the spread of maternity leave programs during the 1970s and 1980s, but it left little trace in the minds of managers, politicians, and scholars. These observers may discount the role of policy because the Supreme Court overturned the key law, but the fact that the EEOC guidelines were overturned does not mean that they did not have effects. They had powerful effects. High-profile legal challenges by employers appear to have amplified those effects, rather than to have dampened them.

The case we examine is typical in many ways. Legislation is just the beginning of lawmaking in the federal system. It is typical that the crucial policy change emerged when the administrative branch sought to interpret congressional intent (Lempert and Sanders 1986; Suchman and Edelman 1996). It is typical that affected parties challenged that interpretation (Burstein and Monaghan 1986; Burstein and Pitchford 1990). It is typical that professionals lobbied executives to comply with the new law even before legal challenges had been resolved (Edelman et al. 1992; Sutton and Dobbin 1996). And it is typical that a quarter century hence, politicians and business leaders appear to have forgotten this episode (Dobbin and Sutton 1998).

Commentators argue that employers created maternity leave policies in response to a change in the labor market, namely feminization. This claim reinforces the idea that, in the United States, the market is powerful and the state is not. That idea becomes self-fulfilling when even the advocates of social change come to believe it. We view the pattern we have documented, of a public policy inducing new business practices and then being forgotten, as evidence of the remarkable rhetorical power of the market in the United States. The inclination to see social practices as driven by market mechanisms, and to believe that practices created by 
other means are artificial and illegitimate appears to have blinded many to the role of the state in improving opportunities for disadvantaged groups.

\section{REFERENCES}

Allison, Paul D. 1995. Survival Analysis Using the SAS System. Cary, N.C.: SAS Institute.

Ashenfelter, Orley, and James Heckman. 1976. "Measuring the Effect of an Antidiscrimination Program." Pp. 46-84 in Evaluating the Labor Market Effects of Social Programs, edited by Orley Ashenfelter and James Blum. Princeton, N.J.: Princeton University Industrial Relations Section.

Baron, James N., Frank R. Dobbin, and P. Devereaux Jennings. 1986. "War and Peace: The Evolution of Modern Personnel Administration in U.S. Industry." American Journal of Sociology 92:350-83.

Baron, James N., P. Devereaux Jennings, and Frank R. Dobbin. 1988. "Mission Control? The Development of Personnel Systems in U.S. Industry." American Sociological Review 53:497-514.

Bender, Marilyn. 1973. "Many Companies Revising Maternity Leave Policies." New York Times, December 10, pp. 61-62.

Blau, Peter M., Cecilia McHugh Falbe, William McKinley, and Phelps K. Tracy. 1976. "Technology and Organization in Manufacturing." Administrative Science Quarterly 21:20-40.

Blau, Peter M., and Richard A. Schoenherr. 1971. The Structure of Organizations. New York: Basic Books.

BNA (Bureau of National Affairs). 1967. A Current Look at: (1) The Negro and Title VII, (2) Sex and Title VII. PPF Survey No. 82. Washington, D.C.: BNA.

. 1975. "Paid Leave and Leave of Absence Policies." Personnel Policies Forum, Survey No. 111. Washington, D.C.: BNA.

—. 1986. Work and Family: A Changing Agenda. Washington, D.C.: BNA.

Burstein, Paul, and Kathleen Monaghan. 1986. "Equal Employment Opportunity and the Mobilization of Law." Law and Society Review 16:355-88.

Burstein, Paul, and Susan Pitchford. 1990. "Social-Scientific and Legal Challenges to Education and Test Requirements in Employment." Social Problems 37:24357.

Business Week. 1976. "A Pregnancy Ruling that Could Cost $\$ 1.6$ Billion.” November 29, p. 41.

California Government Code 12945. 1998. Deering's California Codes Annotated. Dayton, Ohio: Lexis Law Publishing.

California Unemployment Insurance Code 2626. 1998. Deering's California Codes Annotated. Dayton, Ohio: Lexis Law Publishing.

Carruthers, Bruce G., and Terence C. Halliday. 1998. Rescuing Business: The Making of Corporate Bankruptcy Law in England and the United States. Oxford: Clarendon Press.

Citizens' Advisory Council on the Status of Women. 1971. Women in 1970. Washington, D.C.: Government Printing Office.

- 1973. Women in 1972. Washington, D.C.: Government Printing Office.

Costain, Anne N. 1992. Inviting Women's Rebellion: A Political Process Interpretation of the Women's Movement. Baltimore: Johns Hopkins University Press.

DiMaggio, Paul J., and Walter W. Powell. 1983. "The Iron Cage Revisited: Institutional Isomorphism and Collective Rationality in Organizational Fields." American Sociological Review 35:147-60.

Dobbin, Frank, Lauren Edelman, John W. Meyer, W. Richard Scott, and Ann 
Swidler. 1988. "The Expansion of Due Process in Organizations." Pp. 71-100 in Institutional Patterns and Organizations: Culture and Environment, edited by Lynne G. Zucker. Cambridge, Mass.: Ballinger.

Dobbin, Frank, and John R. Sutton. 1998. "The Strength of a Weak State: The Employment Rights Revolution and the Rise of Human Resources Management Divisions." American Journal of Sociology 104:441-76.

Dobbin, Frank, John R. Sutton, John W. Meyer, and W. Richard Scott. 1993. "Equal Opportunity Law and the Construction of Internal Labor Markets." American Journal of Sociology 99:396-427.

Doeringer, Peter B., and Michael J. Piore. 1971. Internal Labor Markets and Manpower Analysis. Lexington, Mass.: Heath.

Dullea, Georgia. 1974. "Sick Leave Pay Still an Issue where Pregnancy Is Concerned." New York Times, April 8, p. 41.

Edelman, Lauren. 1990. "Legal Environments and Organizational Governance: The Expansion of Due Process in the American Workplace." American Journal of Sociology 95:1401-40.

_. 1992. "Legal Ambiguity and Symbolic Structures: Organizational Mediation of Civil Rights Law." American Journal of Sociology 97:1531-77.

Edelman, Lauren B., Steven E. Abraham, and Howard S. Erlanger. 1992. "Professional Construction of the Law: The Inflated Threat of Wrongful Discharge." Law and Society Review 26:47-84.

Edwards, Harry T. 1973. "Sex Discrimination under Title VII: Some Unresolved Issues.” Labor Law Journal 24 (July): 411-23.

Edwards, Mark E. 1996. "Pregnancy Discrimination Litigation: Legal Erosion of Capitalist Ideology under Equal Employment Opportunity Law.” Social Forces 75:24769.

Edwards, Richard. 1979. Contested Terrain: The Transformation of the Workplace in the Twentieth Century. New York: Basic Books.

Elving, Ronald D. 1995. Conflict and Compromise: How Congress Makes the Law. New York: Simon \& Schuster.

Equal Employment Opportunity Commission. 1966. First Annual Report. Washington, D.C.: Government Printing Office.

Fligstein, Neil. 1990. The Transformation of Corporate Control. Cambridge, Mass.: Harvard University Press.

- 1996. "Markets as Politics: A Political-Cultural Approach to Market Institutions." American Sociological Review 61:656-74.

Frank, Meryl, and Robyn Lipner. 1988. "History of Maternity Leave in Europe and the United States." Pp. 3-22 in The Parental Leave Crisis, edited by Edward F. Zigler and Meryl Frank. New Haven, Conn.: Yale University Press.

Freeman, Richard B. 1981. "The Effect of Unionism on Fringe Benefits." Industrial and Labor Relations Review 34:489-509.

Freeman, Richard B., and Morris M. Kleiner. 1990. "The Impact of New Unionization on Wages and Working Conditions." Journal of Labor Economics 8:S8-S25.

Fryburger, L. Bruce. 1975. "Maternity Leave Policies under Title VII." Labor Law Journal 26 (March): 163-73.

Glass, Jennifer, and Tetsushi Fujimoto. 1995. "Employer Characteristics and the Provision of Family Responsive Policies." Work and Occupations 22 (4): 380-411.

Goldin, Claudia. 1986. "Monitoring Costs and Occupational Segregation by Sex: A Historical Analysis." Journal of Labor Economics 4:1-28.

Goodstein, Jerry D. 1994. "Institutional Pressures and Strategic Responsiveness: Employer Involvement in Work-Family Issues." Academy of Management Journal 37 (2): 350-82.

Gordon, David M., Richard Edwards, and Michael Reich. 1982. Segmented Work, Divided Workers. London: Cambridge University Press. 
Gorney, Cynthia. 1984. "Justice and the Price of Pregnancy; Maternity Leave: The Issue Dividing the Feminist Camp." Washington Post, April 5, p. D1.

Granovetter, Mark. 1985. "Economic Action and Social Structure: The Problem of Embeddedness." American Journal of Sociology 91:481-510.

Guthrie, Doug, and Louise Marie Roth. 1999. "The State, Courts, and Maternity Policies in U.S. Organizations: Specifying Institutional Mechanisms." American Sociological Review 64:41-63.

Harrison, Cynthia. 1988. On Account of Sex: The Politics of Women's Issues, $1945-$ 1968. Berkeley: University of California Press.

Hyatt, James C. 1972. "Women Employees Seek Disability Coverage during Pregnancy Leave." Wall Street Journal, December 1, p. 1.

Ingram, Paul, and Tal Simons. 1995. "Institutional and Resource Dependence Determinants of Responsiveness to Work-Family Issues." Academy of Management Journal 38:1466-82.

Jacobsen, Joyce P., and Laurence M. Levin. 1995. "Effects of Intermittent Labor Force Attachment on Women's Earnings." Monthly Labor Review 118 (9): $14-19$.

Jasinoski, Jerry J. 1991. "Weighing the Merits of Family-Leave Act . . Federal Mandate Is Not the Answer." St. Louis Post-Dispatch, May 9, p. 3C.

Kalbfleisch, J. D., and R. L. Prentice. 1980. The Statistical Analysis of Failure Time Data. New York: John Wiley \& Sons.

Kalleberg, Arne L., and Mark E. Van Buren. 1996. "Is Bigger Better? Explaining the Relationship between Organization Size and Job Rewards." American Sociological Review 61:47-66.

Kamerman, Sheila B., Alfred J. Kahn, and Paul Kingston. 1983. Maternity Policies and Working Women. New York: Columbia University Press.

Kessler-Harris, Alice. 1982. Out to Work: A History of Wage-Earning Women in the United States. New York: Oxford University Press.

Klerman, Jacob Alex, and Arleen Leibowitz. 1997. "Labor Supply Effects of State Maternity Leave Legislation." Pp. 65-85 in Gender and Family Issues in the Workplace, edited by Francine D. Blau and Ronald G. Ehrenberg. New York: Russell Sage.

Kochan, Thomas A., Harry C. Katz, and Robert B. McKersie. 1986. The Transformation of American Industrial Relations. New York: Basic Books.

Lempert, Richard, and Joseph Sanders. 1986. An Invitation to Law and Social Science: Desert, Disputes, and Distribution. New York: Longman.

Leonard, Jonathan S. 1984. "The Impact of Affirmative Action on Employment." Journal of Labor Economics 2:439-63.

Lincoln, James R., and Arne L. Kalleberg. 1985. "Work Organization and Workforce Commitment: A Study of Plants and Employees in the U.S. and Japan." American Sociological Review 50:738-60.

Los Angeles Times. 1972. "Rules to Bar Job Bias Based on Pregnancy." Los Angeles Times, April 1, sec. 3, p. 10.

McCammon, Holly. 1996. "Protection for Whom? Maximum Hours Laws and Women's Employment in the United States, 1880-1920." Work and Occupations 23:13264.

McCann, Michael W. 1994. Pay Equity Reform and the Politics of Legal Mobilization. Chicago: University of Chicago Press.

—. 1998. "How Does Law Matter for Social Movements?" Pp. 76-108 in How Does Law Matter? edited by Bryant G. Garth and Austin Sarat. Evanston, Ill: Northwestern University Press, American Bar Foundation.

Meyer, John W. 1994. "Rationalized Environments." Pp. 28-54 in Institutional Environments and Organizations: Structural Complexity and Individualism, edited by W. Richard Scott and John W. Meyer. Thousand Oaks, Calif.: Sage. 
Meyer, John W., and Brian Rowan. 1977. "Institutionalized Organizations: Formal Structure as Myth and Ceremony." American Journal of Sociology 83: 340-63.

Meyer, John W., and W. Richard Scott, eds. 1983. Organizational Environments: Ritual and Rationality. Beverly Hills, Calif.: Sage.

Milkman, Ruth. 1987. Gender at Work: The Dynamics of Job Segregation by Sex during World War II. Urbana: University of Illinois Press.

Milliken, Frances J., Luis Martins, and Hal Morgan. 1998. "Explaining Organizational Responsiveness to Work-Family Issues: The Role of Human Resource Executives as Issue Interpreters." Academy of Management Journal 5:580-92.

National Underwriter. 1974. "Court Finds G.E. Guilty of Sex Bias in Denial of Disability Benefits." National Underwriter, April 20, pp. 1-4.

New Jersey Statutes 43:21-29. 1991. New Jersey Statutes Annotated. St. Paul, Minn.: West Publishing.

New York Times. 1972. "Job Unit Widens Women's Rights." New York Times, March 31, p. A1.

O'Connell, Martin. 1990. "Maternity Leave Arrangements: 1961-85." Work and Family Patterns of American Women, Current Population Reports. Special Studies Series $\mathrm{P}-23$, no. 165 .

Osterman, Paul. 1995. "Work/Family Programs and the Employment Relationship." Administrative Science Quarterly 40:681-700.

Pear, Robert. 1985. "Should Leaves for New Parents Be Mandatory? Mr. Klein: No Concern of Government." New York Times, December 29, sec. 4, p. 16.

Posner, Richard A. 1974. "Theories of Economic Regulation." Bell Journal of Economics 5:335-58.

1997. "The Rise and Fall of Administrative Law." Chicago-Kent Law Review 72:953-63.

Rhode, Deborah L. 1989. Justice and Gender: Sex Discrimination and the Law. Cambridge, Mass.: Harvard University Press.

Roy, William G. 1997. Socializing Capital: The Rise of the Large Industrial Corporation in America. Princeton, N.J.: Princeton University Press.

Ruhm, Christopher J., and Jackqueline L. Teague. 1997. "Parental Leave Policies in Europe and North America." Pp. 133-56 in Gender and Family Issues in the Workplace, edited by Francine D. Blau and Ronald G. Ehrenberg. New York: Russell Sage.

Schatz, Ronald W. 1983. The Electrical Workers: A History of Labor at General Electric and Westinghouse, 1923-1960. Urbana: University of Illinois Press.

Scott, W. Richard. 1995. Institutions and Organizations. Thousand Oaks, Calif.: Sage.

Selznick, Philip. 1957. Leadership in Administration. New York: Harper \& Row. . 1969. Law, Society and Industrial Justice. New York: Russell Sage.

Silverman, Charlotte. 1943. "Maternity Policies in Industry." The Child 8:20-24.

Skrentny, John D. 1996. The Ironies of Affirmative Action: Politics, Culture, and Justice in America. Chicago: University of Chicago Press.

—. In press. "Friends in High Places: The Women's Movement in Costain's Inviting Women's Rebellion.” In Opportunistic Protest? edited by Jeff Goodwin.

Spaeth, Joe L., and Diana P. O'Rourke. 1996. "Design of the National Organizations Study." Pp. 23-44 in Organizations in America, edited by Arne L. Kalleberg, David Knoke, Peter V. Marsden, and Joe L. Spaeth. Thousand Oaks, Calif.: Sage.

Steeh, Charlotte, and Maria Krysan. 1996. "The Polls-Trends. Affirmative Action and the Public, 1970-1995." Public Opinion Quarterly 60:128-58.

Stinchcombe, Arthur. 1965. "Social Structure and Organization." Pp. 142-93 in Handbook of Industrial Organization, edited by James G. March. Chicago: Rand McNally. 
Suchman, Mark C., and Lauren B. Edelman. 1996. "The New Institutionalism in Organizational Analysis." Law and Social Inquiry 21:903-41.

Sunstein, Cass R. 1990. After the Rights Revolution: Reconceiving the Regulatory State. Cambridge, Mass.: Harvard University Press. . 1996. "The APA at Fifty: Health-Health Tradeoffs." University of Chicago Law Review 63:1533-71.

Sutton, John R., and Frank Dobbin. 1996. "The Two Faces of Governance: Responses to Legal Uncertainty in U.S. Firms, 1955 to 1985." American Sociological Review 61:794-811.

Sutton, John R., Frank Dobbin, John W. Meyer, and Richard Scott. 1994. "The Legalization of the Workplace." American Journal of Sociology 99:944-71.

Swenson, Peter. 1992. "Solidarity or Segmentation: Employer Strategies and Labor Supply in Sweden and the United States." Paper presented at the annual meeting of the Industrial Relations Research Association, New Orleans, June.

Taylor, Marylee. 1995. "White Backlash to Workplace Affirmative Action: Peril or Myth." Social Forces 73:1385-1414.

United States Code 42: 2000e(k). 1994. United States Code Annotated. St. Paul, Minn.: West Publishing.

UPI (United Press International). 1984. "Maternity-Leave Law Found Illegal by Judge." New York Times, March 22, p. C5.

Vogel, Lise. 1993. Mothers on the Job: Maternity Policy in the U.S. Workplace. New Brunswick, N.J.: Rutgers University Press.

Waldfogel, Jane. 1997. "Working Mothers Then and Now: A Cross-Cohort Analysis of the Effects of Maternity Leave on Women's Pay." Pp. 92-126 in Gender and Family Issues in the Workplace, edited by Francine D. Blau and Ronald G. Ehrenberg. New York: Russell Sage.

Wall Street Journal. 1972. "EEOC Declares Illegal Employer Policies That Discriminate on the Basis of Pregnancy." Wall Street Journal, April 3, p. 6.

Walsh, Ethel Bent. 1974. "Sex Discrimination and the Impact of Title VII." Labor Law Journal 25 (March): 150-54.

Washington Post. 1996. "Campaign '96: Transcript of the Second Presidential Debate." Washington Post, October 17, p. A12.

White, Harrison C. 1981. "Where Do Markets Come From?" American Journal of Sociology 87:517-47.

Williamson, Oliver. 1981. "The Economics of Organization: The Transaction Cost Approach." American Journal of Sociology 87:548-77. 